RESEARCH ARTICLE

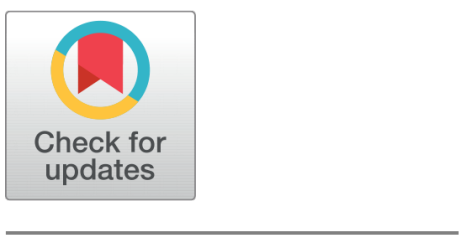

open ACCESS

Received: 02.06.2021

Accepted: 12.07 .2021

Published: 31.07 .2021

Citation: Devikar S, Ansari K, Waghmare C (2021) Solar based hybrid combination of electrocoagulation and filtration process in domestic greywater treatment. Indian Journal of Science and Technology 14(26): 2215-2222.

https://doi.org/

10.17485/IJST/v14i26.890

* Corresponding author.

sanketdevikar@gmail.com

Funding: None

Competing Interests: None

Copyright: ๑ 2021 Devikar et al. This is an open access article distributed under the terms of the Creative Commons Attribution License, which permits unrestricted use, distribution, and reproduction in any medium, provided the original author and source are credited.

Published By Indian Society for Education and Environment (iSee)

ISSN

Print: 0974-6846

Electronic: 0974-5645

\section{Solar based hybrid combination of electrocoagulation and filtration process in domestic greywater treatment}

\author{
Sanket Devikar ${ }^{*}$, Khalid Ansari ${ }^{2}$, Charuta Waghmare ${ }^{2}$ \\ 1 PG Scholar, Department of Civil Engineering, Yeshwantrao Chavan College of Engineering, \\ India \\ 2 Assistant Professor, Department of Civil Engineering, Yeshwantrao Chavan College of \\ Engineering, India
}

\begin{abstract}
Objectives: To evaluate the importance of solar-based Electrocoagulation followed by the filtration process in treating the domestic greywater, analyze each operational process's performance process in highlighting the cost, efficiency and reuse conditions. Analysis: This research aimed to see if the continuous mode EC technique could treat Greywater (GW) with batterypowered solar energy. The EC process running on solar energy is used as a single unit method for Greywater treatment. This explores the hybrid electrocoagulation and filtration process with different electrode material combinations with a flow rate; based on this, and the impact tests are carried out on the flexibility of continuous mode, anode and cathode efficiency. Findings: In this experiment, using a combination of electrodes with different material having continuous flow find about removal efficiencies of different characteristics like COD, Total dissolved solids, Total suspended solids, $\mathrm{pH}$ and Turbidity with the variable in the supply of current with fix detention time. Novelty: Experimental approach based on Solar based Electrocoagulation with filtration mechanism is the new concept of approach for treating Domestic Greywater
\end{abstract}

Keywords: Domestic Greywater; Solar energy; Electrocoagulation; Continuous mode; Controlled flowrate; Filtration

\section{Introduction}

Water is the most essential and crucial element on earth; around 2\% to $3 \%$ water is useable for household chores and drinking water ${ }^{(1)}$. Another use of water is for washing utensils and clothes, for bathing, comes from sinks, wastewater generated from this activity known as Greywater (GW). The greywater is primarily free from organic matters. Wastewater is the combination of greywater and water that comes from latrine, from around $70 \%$ to $80 \%$ is greywater ${ }^{(2)}$. GW common constituent is chemical oxygen demand (COD), Turbidity, TDS, TSS, and Chloride. Treatment of GW is necessary because treated water release in the freshwater medium. Pollutants are harmful, so wastewater needs to be treated for safe disposal. 
Generally, physical, chemical and biological treatment facilities are given to wastewater. The physical treatment process consists of Screening, filtration and sedimentation. Similarly, Chemical and Biological treatment processes consist of Coagulation \& flocculation, chlorination, Adsorption and Rotating Biological contractor, trickling filter, etc. The physiochemical process is found to be effective. The electrochemical process achieved great success in wastewater treatment. Usually, GW consists of less harmful pollutants, so treating greywater using electrochemical technology can be more effective and reasonable ${ }^{(3,4)}$. The Electrocoagulation (EC) process is an electrochemical process that is advanced and efficient. The disintegration of sacrificial anodes forms cations connected to the electric field that starts flocculation of scattering contaminants by decreasing the zeta potential of submerged matter. The metal hydroxide coagulates the impurities of fluid, and the cathode form hydrogen bubbles allow the floatation of organic flocks ${ }^{(5-9)}$. Researchers get by EC process that it is very efficient, easy to handle, environmentally friendly, and cost-efficient. EC has its advantages less detention time, no chemical required, rapid floc formation, easy disposal of sludge. Many researcher use batch process for the EC process to remove COD, BOD, Turbidity, TDS, TSS, Chlorides. Higher the current density and lower the flow rate than higher removal of pollutants given by Marmanis et al., the electrodes use in the EC process are Aluminum $\mathrm{Al}$, Iron Fe. The electrode $\mathrm{Al}$ has more efficiency than electrode $\mathrm{Fe}^{(4,10)}$.

The reactions on electrode due to current density are as follow:

For Al electrodes:

$$
\begin{gathered}
A l \rightarrow A l^{3+}+3 e^{-} \\
3 \mathrm{H}_{2} \mathrm{O}+3 \mathrm{e}-\rightarrow 3 / 2 \mathrm{H}_{2}+3 \mathrm{OH}^{-}
\end{gathered}
$$

For Fe electrodes:

$$
\begin{gathered}
\mathrm{Fe} \rightarrow \mathrm{Fe}^{2+}+2 e^{-} \\
2 \mathrm{H}_{2} \mathrm{O}+2 \mathrm{e}-\rightarrow \mathrm{H}_{2}+2 \mathrm{OH}^{-}
\end{gathered}
$$

The researcher has successfully studied the Solar Powered Electrocoagulation (SPEC) device setup in remote Australian communities for the treatment of water and wastewater ${ }^{(11-13)}$. The impact on the environment using solar energy is very minimal, and thus, the EC process using solar panel is attractive; it makes the EC process cost-efficient. For remote water treatment applications, photovoltaic solar panels are a magnificent decision due to their durability, particularity, low support and low commotion ${ }^{(14)}$. Our primary aim is to research the solar-powered EC process's suitability in continuous flow for contaminants removal from domestic greywater. Sun based fueled DC supply through batteries is utilized in the EC measure test. To improve the Solar EC method's operating conditions for maximum pollutant removal, experiments were performed and analyze the effects of wastewater operating parameters such as current density and detention period on removal efficiency of COD, Turbidity, TDS, $\mathrm{pH}^{(1)}$.

\section{Material and methods}

\subsection{Sampling of Greywater}

In this experiment, samples collected from houses situated at Nagpur, Maharashtra. Wastewater contains fluid from the kitchen, sinks, laundry, bathing. Grab sampling is used to collect samples. The collected samples are stores properly in polypropylene bottles at $4^{\circ} \mathrm{C}$. Initial testing was performed on samples for $\mathrm{pH}$, COD, Total Solids, Conductivity, Turbidity, Chlorides. Different tests prescribed in Standard Methods, all samples were assets with initial and final output ${ }^{(5,15-18)}$.

\subsection{Experimental set up at Laboratory}

EC process performs in EC cell made up of an acrylic material having dimensions of $(190 \times 100 \times 160) \mathrm{mm}(\mathrm{L} \times \mathrm{B} \times \mathrm{H})$ respectively net capacity of 3 litres. The EC unit contains four electrodes arrange in one-line aluminium (Al) and Iron (Fe). Dimension of electrodes $16.5(\mathrm{H}) \mathrm{cm} \times 4.5(\mathrm{~L}) \mathrm{cm} \times 0.02(\mathrm{~W}) \mathrm{cm}$ they are placed in linear and gap between each electrode plate is $5 \mathrm{~cm}$. In this experiment, the arrangement of the electrodesis Al-Fe-Al-Fe, Fe-Al-Fe-Al. Electrodes are removable so that cleaning of electrodes can be done quickly in distilled water. An additional $2^{\text {nd }}$ tank provided to reactors to take out floating material above GW. The orifice size of $10 \mathrm{~mm}$ present at the bottom of the $2^{\text {nd }}$ tank from where continuous flow is maintained, followed by the filtration process. The electrodes are connected in parallel connection to the charge controller through batteries. The Solar based photovoltaic module, charge regulator and battery are available, and it comprises one board of 60W limit. 


\subsection{Experimental procedure}

The EC tests did unsteady flow each sample fed to the EC unit via storage tank with foreordained stream rates for 20 minutes of the detention period. Diversecurrent densities ranging $(6-18) \mathrm{A} / \mathrm{m}^{2}$ are applied. GW present in tank flocs is formed because of sacrificial electrodes with constant current density provided to an electrode. After the EC process, water goes to the $2^{\text {nd }}$ tank where a $10 \mathrm{~mm}$ orifice is present at the bottom; water goes through an orifice to the filtration unit and contains firstly sand, activated carbon, aggregates, and pebbles. It takes 5 minutes to travel water from the orifice to the bottom opening filtration unit and then filtered water stored at glass beaker for final testing's.

$$
\text { The flow rate of water determined by } Q(\text { discharge })=v(\text { volume }) / t(\text { time })
$$

Where, $\mathrm{Q}-\mathrm{m}^{3} / \mathrm{sec}$

The anodes are separated from the EC unit and flawlessly washed with prior, resulting in each race, faucet water. Anodes, at that point, are placed in the gadget once more [Figure 1].

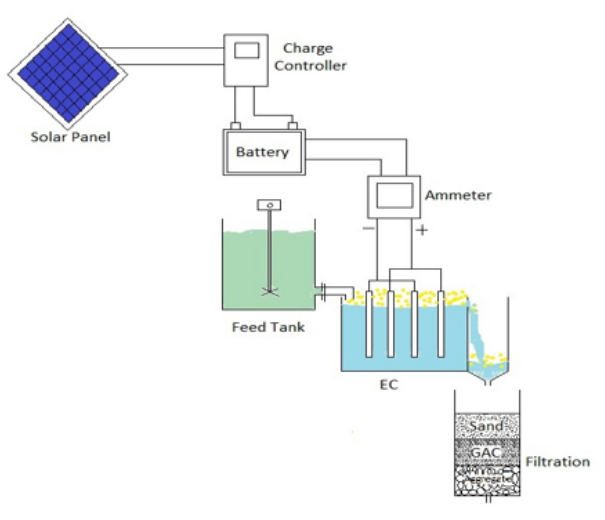

(a)

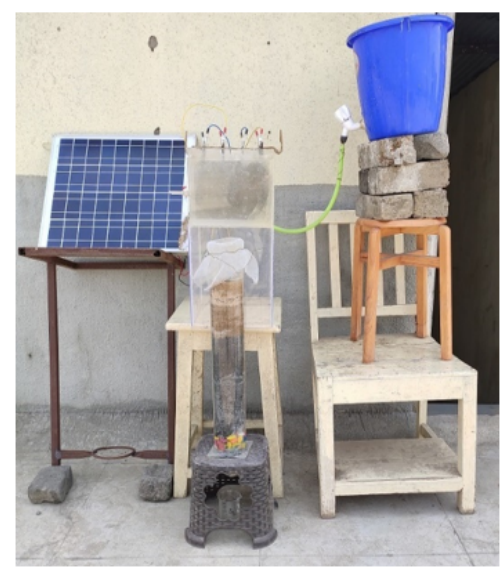

(b)

Fig 1. Research Scale Experimental arrangement of Solar Powered Electrocoagulation and Filtration Process

\subsection{Analysis of experiment}

Samples are regularly obtained and checked for their characteristics such as $\mathrm{pH}$ by $\mathrm{pH}$ meter, conductivity, Turbidity by turbidity meter, COD by COD digester and digital spectrometer, TSS and TDS in drying oven for the impact and effluent of the laboratory treatment device. The removal efficiency of each parameter was calculated using the equation ${ }^{(13)}$. $\operatorname{Re}(\%)=$ $\left[\left(\mathrm{C}_{\text {intial }}-\mathrm{C}_{\text {final }}\right) / \mathrm{C}_{\text {initial }}\right]^{\star} 100^{(13)}(6)$ where $\mathrm{C}_{\text {initial }}$ and $\mathrm{C}_{\text {final }}$ are initial and final concentration.

\section{Results and Discussion}

Table 1. Greywater characteristics feed as Influents to EC and F process, N: 12 samples. Initial \& Final Characteristics of Greywater recorded in EC process:

\begin{tabular}{lll}
\hline Parameters & Initial Value & Final Value \\
\hline $\mathrm{pH}$ & 8.9 & 7.4 \\
Turbidity (NTU) & 120 & 11 \\
TDS (mg/lit) TSS (mg/lit) & 250145 & 10515 \\
COD (mg/lit) & 550 & 83 \\
Chloride (mg/lit) & 41 & 13 \\
Sulphate(mg/lit) & 73 & 28 \\
Ammonia Nitrogen (mg/lit) & 6.9 & 1.3 \\
Orthophosphorus(mg/lit) & 7.5 & 1.15 \\
\hline
\end{tabular}


Table 2. Continuous Flow Rate detail

\begin{tabular}{ll}
\hline Serial No. & $\mathrm{Q}=1 / \mathrm{min}$ (discharge) \\
\hline 1 & 0.04 \\
2 & 0.10 \\
2 & 0.12 \\
\hline
\end{tabular}

\subsection{Effect of current densities on Electrodes}

The vital parameters influencing EC process performance are current density applied to electrodes and inlet flow rate values in the continuous EC system. Various experiments for EC were performed to study the effects of current density and hydraulic detention time by varying current density and detention time. The noticed expulsion efficiencies for Turbidity, COD, and TDS are shown for different current densities and detention time. The outcomes show that current density and operating time usefully affect the EC interaction.

Figure $2(\mathrm{a} \& \mathrm{~b})$ shows that the elimination of COD was very efficient for hydraulic detention Period 20 minute with varying current density $6-18 \mathrm{~A} / \mathrm{m}^{2}$. COD removal efficiency achieved in this experiment with different electrode combination Al-Fe$\mathrm{Al}-\mathrm{Fe} \& \mathrm{Fe}-\mathrm{Al}-\mathrm{Fe}-\mathrm{Al}$ is $(78.5 \%, 72.21 \%, 65.9 \%$ \& $85.33 \%),(82.12 \%, 77.6 \%)$ at optimum condition for flow rate of $(4.25,6.04$ and 7.4) $1 / \mathrm{hr}$. Due to the lower output of $\mathrm{Al}(\mathrm{OH}) 3$ during the hydraulic detention Period between 0 - $10 \mathrm{~min}$, COD removal was comparatively lower. Increased efficiency of removal with elevating current density is due to the elevated rate of $\mathrm{Al}$ dissolution. Increasing the dissolution rate of $\mathrm{Al}^{3}+$ increases the formation of $\mathrm{Al}(\mathrm{OH}) 3$ and the release of $\mathrm{H}_{2}$, thereby reducing the diameter of the $\mathrm{H}_{2}$ bubble. Electrolysis time also affects EC effectiveness. Higher removal is provided by a longer electrolysis time ${ }^{(4,19)}$. The highest removal efficiency achieved $95 \%$ in the process, increasing operating time in EC.

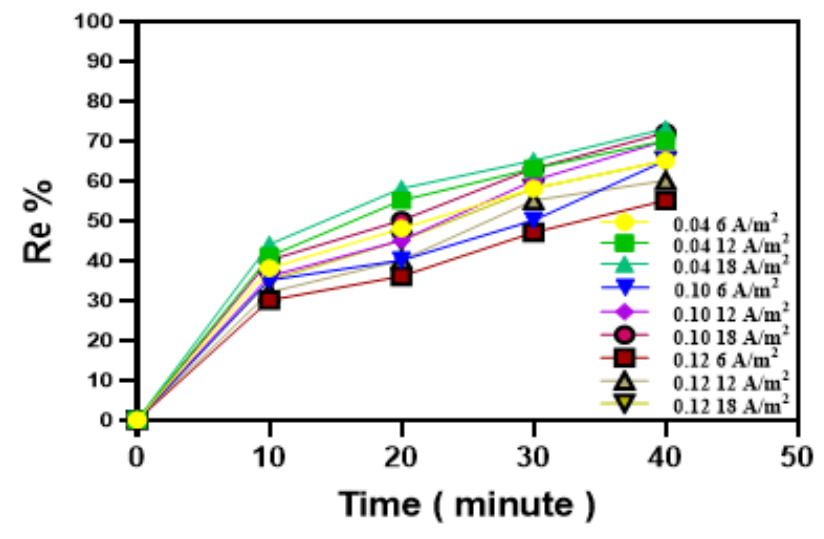

(a)

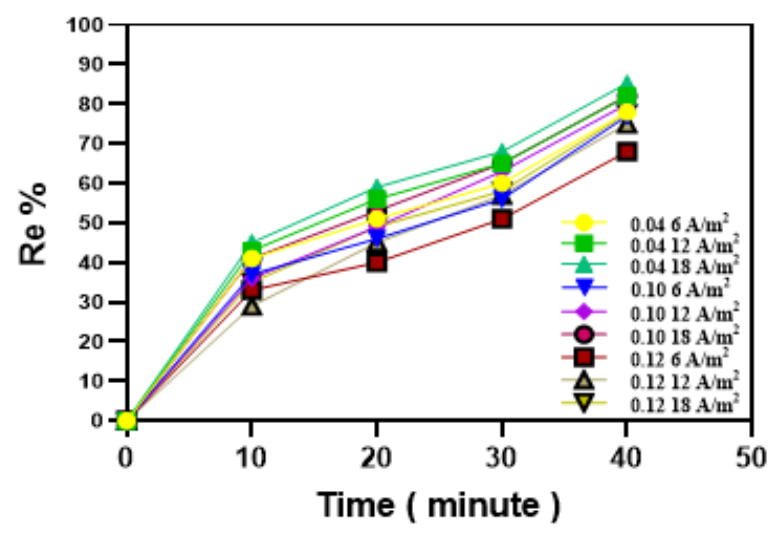

(b)

Fig 2. Effect of applied voltages and operating time for COD removal during SPEC \& Filtration Process for(a) Al-Fe-Al-Fe \& (b) Fe-Al-Fe-Al electrode combination

Figure $3(\mathrm{a} \& \mathrm{~b})$ shows that turbidity removal is increasing with a varying current density of $6-18 \mathrm{~A} / \mathrm{m}^{2}$ for hydraulic detention time 20 minute. Turbidity removal efficiency achieved in this experiment with different electrode combination Al$\mathrm{Fe}-\mathrm{Al}-\mathrm{Fe} \& \mathrm{Fe}-\mathrm{Al}-\mathrm{Fe}-\mathrm{Al}$ is $89.3 \%, 85 \%, 80 \%$ \& $91.66 \%, 87.3 \%, 83 \%$ at optimum condition for flow rate of $(4.25,6.04$ and 7.4) $\mathrm{l} / \mathrm{hr}$. Turbidity removal increased by $91.66 \%$ in this scenario when the current density is increased to $18 \mathrm{~A} / \mathrm{m}^{2}$. When the flow rates expand, the productivity of turbidity evacuation diminishes for a similar current density. Filtration unit of sand and aggregate use for removal of colour and Turbidity achieved $95 \%$ removal efficiencies. 


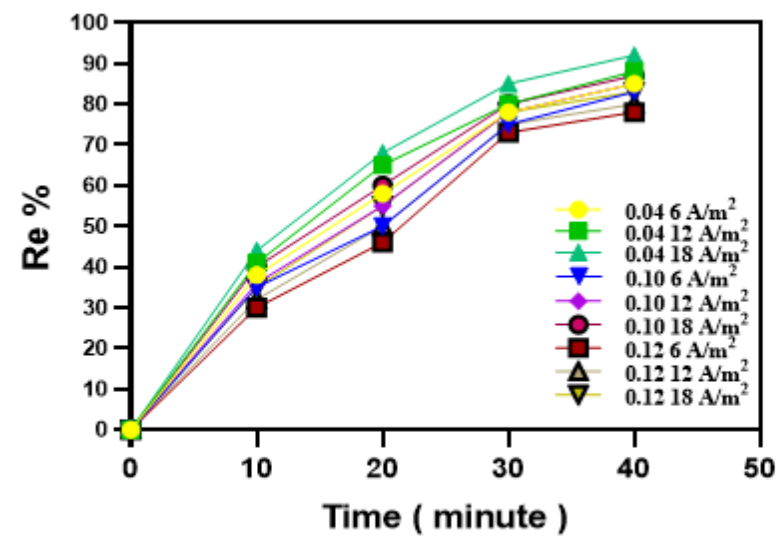

(a)

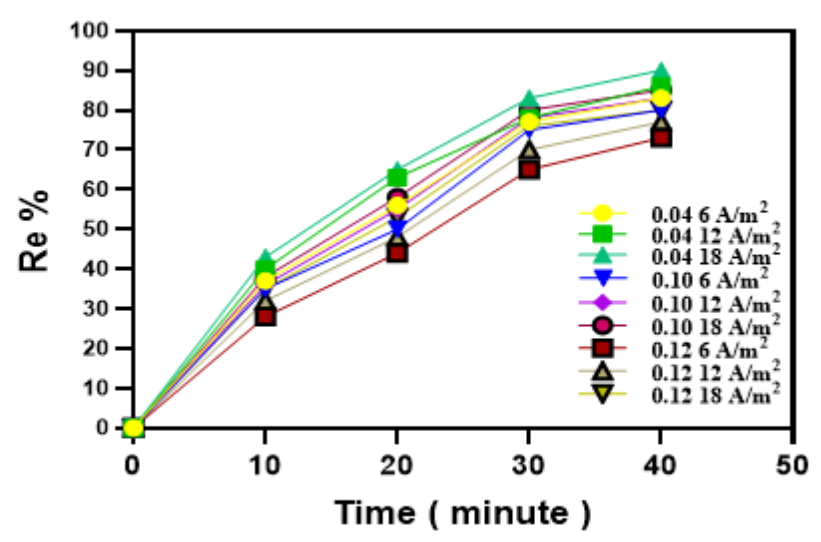

(b)

Fig 3. Effect of turbidity removal efficiency during SPEC \& Filtration Process for (a) Al-Fe-Al-Fe \& (b) Fe-Al-Fe-Al electrode combination

Figure $4(\mathrm{a} \& \mathrm{~b})$ shows that at a hydraulic detention period of 20 minute and $18 \mathrm{~A} / \mathrm{m}^{2}$ optimum TDS removal efficiency observed at flow rate of $(4.25,6.04$ and 7.4$) 1 / \mathrm{hr}$ is $60 \%, 56.3 \% \& 49.8 \%$.

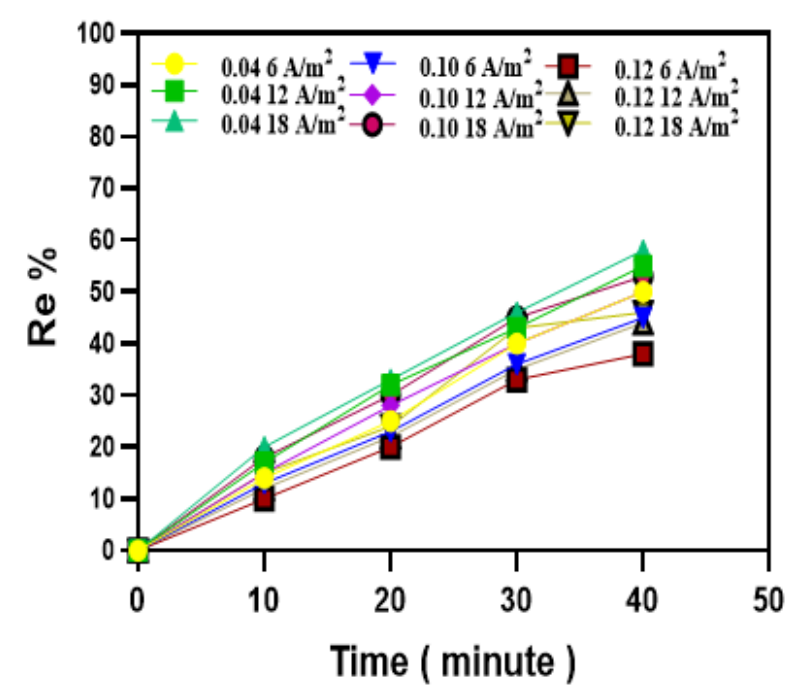

(a)

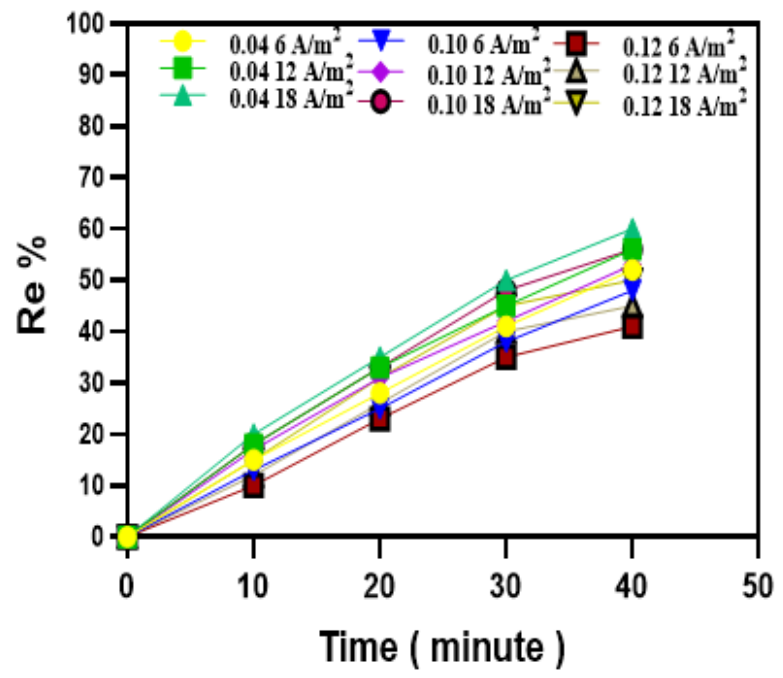

(b)

Fig 4. Effect of TDS removal efficiency during SPEC \& Filtration Process for (a) Al-Fe-Al-Fe \& (b) Fe-Al-Fe-Al electrode combination

\subsection{Effect of $\mathrm{pH}$}

Firstly, $\mathrm{pH}$ increases. It is acidic, and $\mathrm{pH}$ decreases whenit is alkaline; EC acts as a $\mathrm{pH}$ neutralizer using aluminium, iron as an electrode material. EC treatment refers to wastewater treatment, which prevents further $\mathrm{pH}$ change of the effluent Figure 5. The $\mathrm{pH}$ of the effluent is obtained within the 7.4-8.9 range. All EC studies show that $\mathrm{pH}$ ranging from $6-9$ highest efficiency of removal characteristics. 


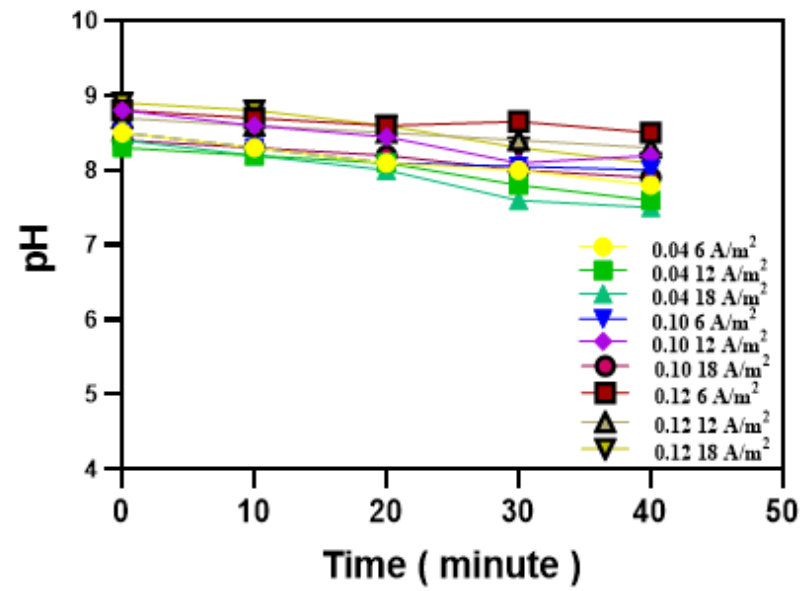

(a)

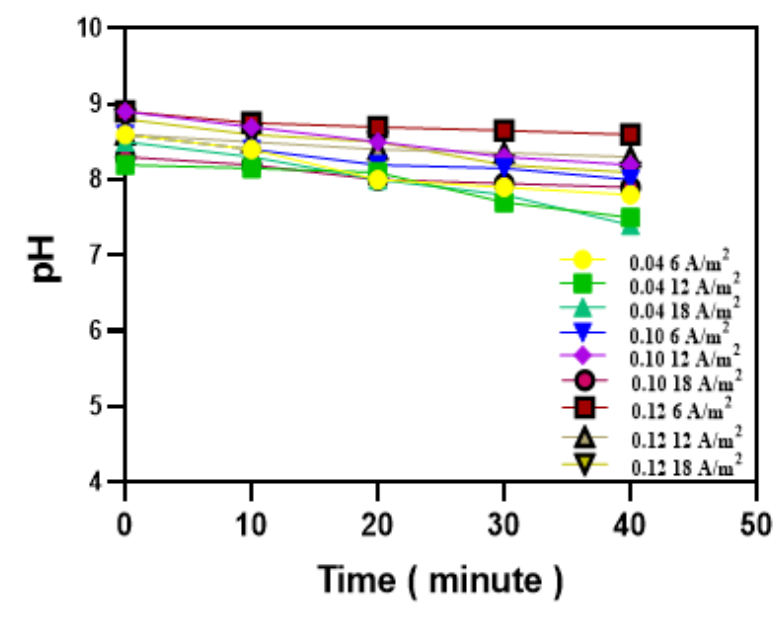

(b)

Fig 5. Effect of $\mathrm{pH}$ during SPEC \& Filtration Process for(a) Al-Fe-Al-Fe \&(b) Fe-Al-Fe-Al electrode combination

\subsection{Effect of material}

In an EC cell, the hybrid electrode material is critical because it determines the reactions that occur due to colloidal charges determined by the cation present in the solution. According to the researchers, aluminium electrodes have a higher treatment efficiency than iron electrode because $\mathrm{Al}(\mathrm{OH})_{3}$ forms colloidal particles that act as precipitates and are dependent on the $\mathrm{pH}$ of the solutions. As a result, COD removal efficiency is higher in the Fe-Al-Fe-Al combination than in other combinations. In the $18 \mathrm{~A} / \mathrm{m}^{2} \mathrm{Fe}-\mathrm{Al}-\mathrm{Fe}-\mathrm{Al}$ configurations, rapid floc formation was observed once more.

\subsection{Effect of flowrate}

The Flowrate $(\mathrm{Q})$ to the reactor influences the treatment proficiency of an EC interaction. Reduction in flow rate allows elevating in hydraulic retention time in the EC reactor, allowing the produced metal hydroxides flocs to re-establish, removal mechanisms to improve. During the EC phase, mixing is also needed to advance floc development and precipitation. The effect of flow rate on COD removal in greywater was investigated for flow rates ranging from $0.04-0.07 \mathrm{l} / \mathrm{min}$ and a detention period of 20 minutes at $18 \mathrm{~A} / \mathrm{m}^{2}$. Increased flow rate from 0.04 to $0.07 \mathrm{l} / \mathrm{min}$ decreased COD removal efficiencies from $78.5 \%$ to $65.9 \%$ for $\mathrm{Al}-\mathrm{Fe}$ electrodes combination and $85.33 \%$ to $77.6 \%$ for Fe-Al electrode combination. At flow rates of 0.04 and $0.07 \mathrm{l} / \mathrm{min}$, the turbidity removal efficiencies with $\mathrm{Al}$ and $\mathrm{Fe}$ electrodes were $89.3 \%, 91.66 \%$ and $80 \%, 83 \%$, respectively, after 20 minutes of the EC process.

\subsection{Cost Analysis}

The fault of this innovation is affected by all out working expense including anode material, utilization of energy, gifted labourers, muck examination delivered with various terminal course of action effectively acted in various working time and current thickness. For down to earth execution of EC measure on genuine premise it is critical to be affordable and the central point answerable for keeping up the equivalent is Cost of activity. Operational rate (OPC) of ECF measure incorporates electrical energy utilized, cost of terminal utilization and upkeep cost for removal of ooze on landfill, filtration media and other fixed charges which is relied upon to be Rs $1.5 \mathrm{~kg} / \mathrm{m}^{3}$. The costs of terminal material were Rs. 30/kg and Rs. 130/kg for iron and aluminium separately. On complete, during EC measure Rs. $6.5 \mathrm{~kg} / \mathrm{m}^{3}$ and Rs. $3.5 \mathrm{~kg} / \mathrm{m}^{3}$ of Al and Fe cathode individually was devoured. Thus working expense is a vital worry in plan the EC reactors to fulfil the necessary state of medicines to decrease the upkeep just as compound expense of treatment which is utilized as coagulants helps. The Cost energy required at the optimum operating condition to treat Greywater at detention time $20 \mathrm{~min}$ and current density $18 \mathrm{~A} / \mathrm{m}^{2}$ is zero. The power availed is solar energy, thus the proposed photovoltaic EC process is sustainable \& cost effective. 


\section{Calculation -}

$$
\begin{aligned}
& \text { OPc }=\text { Cost energy }+ \text { Cost electrode }+ \text { Cost maintenance } \\
& \text { Cost of Energy, Cost energy }\{\mathrm{kWh} / \mathrm{m} 3\}=\{(U * i * t o) / V\} \\
& \text { Cost of Electrode, Cost electrode }\{\mathrm{kg} / \mathrm{m} 3\}=\{(i * t o * M w) /(z * F * V)\}
\end{aligned}
$$

\begin{tabular}{|c|c|c|c|c|c|c|}
\hline EC+ Filtration & $\mathbf{U}$ & $\mathrm{CD}(\mathrm{A})$ & $\mathbf{C}_{\text {energy } K W h / m^{3}}$ & $\mathbf{C}_{\text {electode } K g ~ A l / m^{3}} \mathrm{~kg} \mathrm{Fe} / \mathrm{m}^{3}$ & $\mathbf{C}_{\text {Main }}(\mathbf{I N R})_{\mathrm{kg} / \mathrm{m}^{3}}$ & $\mathrm{OP}_{c}$ inINR $/ \mathrm{m}^{3}$ \\
\hline Al-Fe-Al-Fe & 18 & 0.8 & - & 0.023 & 2.1 & 6.53 \\
\hline $\mathrm{Fe}-\mathrm{Al}-\mathrm{Fe}-\mathrm{Al}$ & 18 & 0.8 & - & 0.042 & 2.1 & 5.96 \\
\hline
\end{tabular}

\section{Conclusion}

The continuous SPEC method of the laboratory scale shown in the present study is substantially efficient using batteries. The removal efficiencies observed at $18 \mathrm{~A} / \mathrm{m}^{2}$ current density and 20 min detention time for flow rate of $(4.25,6.04$ and 7.4$) \mathrm{l} / \mathrm{hr}$ for COD $(85.33 \%, 82.12 \%, 77.6 \%)$, TDS ( $60 \%, 56.3 \%, 49.8 \%)$, and Turbidity $(92.2 \%, 87.8 \%, 83.9 \%)$ respectively. The pH of the effluent is obtained within the 7.4-8.9 range. Efficiency decreases when the flow rate increases. Elements influencing EC measure are whole between terminals course of action, the material of anodes utilized in measure, cathodes extremity and thickness of current, distinction in $\mathrm{pH}$ and conductivity. For Greywater treatment, the proposed sun-based force electrocoagulation cell reactor setup is feasible with cost estimation of Rs. $6.5 \mathrm{~kg} / \mathrm{m}^{3}$ and Rs. $3.5 \mathrm{~kg} / \mathrm{m}^{3}$ for Al and Fe materials. The future interest of sunlight-based force EC for domestic greywater treatment, municipal wastewater, and industrial wastewater is exceptionally savvy.

\section{References}

1) Moussa DT, El-Naas MH, Nasser M, Al-Marri MJ. A comprehensive review of electrocoagulation for water treatment: Potentials and challenges. Journal of Environmental Management. 2017;186:24-41. Available from: https://dx.doi.org/10.1016/j.jenvman.2016.10.032.

2) Lesjean B, Gnirss R. Grey water treatment with a membrane bioreactor operated at low SRT and low HRT. Desalination. 2006;199(1-3):432-434. Available from: https://dx.doi.org/10.1016/j.desal.2006.03.204.

3) Shrivastava N, Honade S, Udakhe J. Electrocoagulation as an alternative treatment for wastewater generated from scouring of merino wool. Indian Journal of Environmental Protection. 2014;34(7):529-533.

4) Moussa DT, El-Naas MH, Nasser M, Al-Marri MJ. A comprehensive review of electrocoagulation for water treatment: Potentials and challenges. Journal of Environmental Management. 2017;186:24-41. Available from: https://dx.doi.org/10.1016/j.jenvman.2016.10.032.

5) Ghaitidak DM, Yadav KD. Characteristics and treatment of greywater-a review. Environmental Science and Pollution Research. 2013;20(5):2795-2809. Available from: https://dx.doi.org/10.1007/s11356-013-1533-0.

6) Li F, Wichmann K, Otterpohl R. Review of the technological approaches for grey water treatment and reuses. Science of The Total Environment. 2009;407(11):3439-3449. Available from: https://dx.doi.org/10.1016/j.scitotenv.2009.02.004.

7) Pidou M, Memon FA, Stephenson T, Jefferson B, Jeffrey P. Greywater recycling: treatment options and applications. Proceedings of the Institution of Civil Engineers - Engineering Sustainability. 2007;160(3):119-131. Available from: https://dx.doi.org/10.1680/ensu.2007.160.3.119.

8) Li F, Wichmann K, Otterpohl R. Review of the technological approaches for grey water treatment and reuses. Science of The Total Environment. 2009;407(11):3439-3449. Available from: https://dx.doi.org/10.1016/j.scitotenv.2009.02.004.

9) Vakil KA, Sharma MK, Bhatia A, Kazmi AA, Sarkar S. Characterization of greywater in an Indian middle-class household and investigation of physicochemical treatment using electrocoagulation. Separation and Purification Technology. 2014;130:160-166. Available from: https://dx.doi.org/10. 1016/j.seppur.2014.04.018.

10) Marmanis D, Dermentzis K, Christoforidis A, Ouzounis K, Moumtzakis A. Electrochemical treatment of actual dye house effluents using electrocoagulation process directly powered by photovoltaic energy. Desalination and Water Treatment. 2014;p. 1-6. Available from: https://dx.doi. org/10.1080/19443994.2014.966330.

11) Sharma G, Choi J, Shon HK, Phuntsho S. Solar-powered electrocoagulation system for water and wastewater treatment. Desalination and Water Treatment. 2011;32(1-3):381-388. Available from: https://dx.doi.org/10.5004/dwt.2011.2756.

12) Zhang S, Zhang J, Wang W, Li F, Cheng X. Removal of phosphate from landscape water using an electrocoagulation process powered directly by photovoltaic solar modules. Solar Energy Materials and Solar Cells. 2013;117:73-80. Available from: https://dx.doi.org/10.1016/j.solmat.2013.05.027.

13) Eyvaz MT, Gürbulak E, Kara S, Yüksel E. Modern Electrochemical Methods in Nano, Surface and Corrosion Science;vol. 8. 2014.

14) Prakash S, Srivastava S. Solar energy and its future role in the Indian economy. International Journal of Environment Science: Dev Monit. 2013;4(3). Available from: https://www.ripublication.com/ijesdmspl/ijesdmv4n3_18.pdf.

15) Metcalf, Eddy. Wastewater Engineering Treatment, Disposal, and Reuse. 3rd ed. New York. McGraw-Hill. 2003. Available from: https://searchworks. stanford.edu/view/525308.

16) Otterpohl R, Albold A, Oldenburg M. Source control in urban sanitation and waste management: ten systems with reuse of resources. Water Science and Technology. 1999;39(5):153-160. Available from: https://dx.doi.org/10.2166/wst.1999.0234. 
17) Eriksson E, Auffarth K, Eilersen AM, Henze M, Ledin A. Household chemicals and personal care products as sources for xenobiotic organic compounds in grey wastewater. Water SA. 2003;29:135-146. Available from: https://dx.doi.org/10.4314/wsa.v29i2.4848.

18) Sibel B, Ozgeturkay. Domestic greywater treatment by electrocoagulation using hybrid electrode combinations. Journal of Water Process Engineering. 2016;10:56-66. Available from: https://www.sciencedirect.com/science/article/abs/pii/S2214714416300319.

19) Makwana AR, Ahammed MM. Electrocoagulation process for the post-treatment of anaerobically treated urban wastewater. Separation Science and Technology. 2017;52(8):1412-1422. Available from: https://dx.doi.org/10.1080/01496395.2017.1288139. 